Est Ag 35 (2000) 237-270

\title{
Jesús y los cínicos (II)
}

\section{1. Teoría sobre los orígenes cristianos}

Como sabio cínico, Jesús nunca tuvo intención de lanzar un programa ni fundar movimiento de ninguna clase; diversos grupos envueltos en experimentos sociales innovadores hicieron de él un fundador.

Mack divide estos grupos en dos categorías: Los movimientos de Jesús de Palestina y de la parte del Sur de Siria y los Cultos de Cristo de Siria del Norte, Asia Menor y Grecia. Las diferencias entre estos dos grandes grupos son claras en sus prácticas y creencias y sobre todo en lo referente a la idea de Jesús. Solamente les unía un rasgo que arranca del Jesús histórico: la práctica de encontrarse juntos para comidas comunitarias que se aprovechan para conversar. Veamos las características de estos grupos.

\section{2. Los movimientos de Jesús}

Mack distingue cinco tipos de movimientos o congregaciones diferentes. Todos ellos conservan la memoria de Jesús y se entienden como movimientos judíos de reforma. Ninguno dio importancia alguna a la muerte de Jesús, ni a la resurrección y apariciones. Evidentemente tampoco reconocieron a Jesús como el Señor de una sociedad religiosa nueva. Ingresar en estos grupos no significaba la ruptura con el judaísmo. Nada les obligaba a separarse de su pasado ${ }^{176}$. Estos movimientos estaban más cerca de las enseñanzas del Jesús histórico que del Cristo; son las formas normales y comprensibles de seguimiento de un sabio cínico, muy lejos por cierto de los Cultos de Cristo que son una aberración.

176. A Myth, 96-97. 


\section{El Grupo Q}

El grupo más importante de estos Movimientos de Jesús es el formado por itinerantes de Galilea cuyo manual fue el documento Q. Eran predicadores de estilo cínico y los más fieles seguidores de Jesús. Predicaban el reino de Dios que no tenía nada de escatológico o apocalíptico. Al contrario la idea del reino de este grupo, igual que la de Jesús, debe interpretarse a la luz del pensamiento cínico: un modo contracultural de entender la vida basado en un sistema de valores y una moral para una comunidad alternativa. El reino de Dios es probablemente una construcción temprana de algún movimiento de Jesús y no deriva de los judíosi77.

En El Evangelio Perdido Mack ha desarrollado más la evolución de la comunidad que está detrás de Q. Distingue cinco etapas en la historia social de Q.

La primera etapa llamada Pre $Q-1$ es reconocible sólo por la reconstrucción de un conjunto de aforismos reelaborados después por el redactor de Q1. En este estadio se sorprende una crítica mordaz hacia valores comúnmente apreciados. Respiran simpatía por una vida más sencilla, aunque sin proponer un programa concreto ${ }^{178}$.

En la segunda etapa, el tesoro se enriquece con imperativos mediante los cuales se trata de imponer el mejor de vida posible dentro de una determinada escala de valores. Estos valores apuntan a una forma de vida muy semejante a la recomendada por los filósofos cínicos del periodo grecorromano como la crítica de la riqueza, llamada a la pobreza voluntaria, audacia en presencia de aquellos que tienen el poder y la autoridad, desprendimiento de la familia, fuerte sentido de vocación, independencia e invitación a mendigar sin vergüenza. Esta forma de vida que el grupo $Q$ pretende llevar a cabo recibe el nombre de reino de Dios. Aparece así una ligera diferencia con los cínicos, nada interesados en resaltar el aspecto divino del orden natural. Otra diferencia aparece con los cínicos: en el grupo de Jesús se detecta una conciencia intensificada de pertenecer a un movimiento y una visión social. Imperativos primitivos han evolucionado hacia unas reglas comunitarias junto con argumentos. Estos dos ingredientes insinúan el proceso de formación social del grupo: los integrantes del grupo necesitan un cuidado aparte, por eso invocan

177. A Myth, 71 .

178. Enumera 17 dichos reconstruidos pertenecientes a este estadio. El mismo dice que "al principio esas perogrulladas parecen un poco banales. Pero al reflexionar se advierte que critican los valores convencionales". Invito al lector que compruebe si bastantes de los dichos reconstruidos son medianamente brillantes como para ser recordados. Decir que "si la sal es insípida, no sirve para nada", o que "un ciego no puede guiar a otro ciego" o que "un buen árbol no da fruto podrido", no son frases para ser recordadas. 
a Dios como padre, concepto de Dios muy extendido en la época y que no significa nada especial, sino que la comunidad se va viendo como familia.

A continuación descubre Mack un estadio Post Q1/pre Q2 necesario para explicar fenómenos muy especiales presentes en Q2. La actividad más importante del grupo ya no tenía lugar en el escenario público. Al extenderse el grupo en diversos lugares, se empezó a hacer hincapié en el cultivo de nuevos adeptos. La actividad pasó de la esfera pública al grupo doméstico, de este modo se preparaba el terreno para los cambios sociales reconocibles en Q2.

El cuarto estadio presente en Q2 marca un cambio repentino. Ya no habla un maestro, habla un profeta que juzga un mundo malvado, que amenaza con terribles castigos. Aparece Juan con un discurso agobiante. El reino de Dios es la esfera del dominio divino, oculto ahora, que será revelado al final de los tiempos. La amenaza de ser sorprendidos en un juicio final está presente como hilo conductor de toda la trama. Los amenazados son aquellos que han frustrado la misión del grupo. Los fariseos son escogidos como blanco de la ira que respira el grupo. Pero las críticas dirigidas a ellos como las invectivas contra la generación mala y perversa o contra las ciudades del lago no dan en el blanco, son oyentes meramente en el papel; lo único que demuestran es el fracaso de la misión del grupo Q. Al extenderse más difícil resultó mantener las normas de obligado cumplimiento. Fue preciso imaginar a Jesús dando instrucciones que delimitasen el camino auténtico. Esta intensificación de identidad grupal fue el primer paso para la fábrica de mitos que se encuentra en Q2 y que lleva consigo apropiación creativa y arreglos inteligentes de figuras míticas ajenas. Q vincula a los fariseos con la historia de los antepasados que habían maltratado a los profetas. La epopeya bíblica fue leída como si allí se encontrara una crítica devastadora de los fariseos. Un elemento importante del mito de orígenes incluye la expansión de la visión de Jesús mediante la apropiación de dos figuras mitológicas: la sabiduría de Dios y el hijo del hombre. En contra del radical igualitarismo de los primeros estratos, Jesús es ahora visto como una figura de autoridad, sabiduría divina, visionario apocalíptico y celestial hijo del hombre. Está claro que toda esta labor es una magnífica reimaginación o mitificación del sabio cínico y que vino impuesta por la necesidad de identificación y consolidación del grupo.

Finamente Mack postula la etapa de Q3179, que coloca tras la guerra judeorromana. Al igual que los demás grupos judíos necesitaron repensar el papel

179. A este estadio Mack atribuye más material que J. Kloppenborg. Aparte de 4,1-13; 11 , 42d; 16,17, Mack asigna también a Q 10,21-22; 11,27-28; 12,5; 13,34-35; 16,16.18 (versículo no asignado por J. Kloppenborg a ningún estrato); 18,29. Cfr. El Evangelio, 181. 
que el grupo podía y debía representar tras la catástrofe. Es entonces cuando la mitologización llegó a un grado extremo: se impuso la visión de Jesús como hijo de Dios. Los conceptos mitológicos anteriores se unificaron en la figura única del hijo de Dios. Es entonces cuando se comienza a hacer uso de la imaginería del templo, cuya destrucción se aprovechó para que el grupo de Q se viera como el heredero de Israel. Al mismo tiempo se echa mano de las Escrituras, pero no para acusar a Israel de no cumplirlas, sino como pauta ética apropiada para el reino de Dios. Sorprende Mack en este estadio un acercamiento a la sensibilidad judía, sin llegar desde luego a confundirse con el judeo-cristianismo ${ }^{180}$.

Poco tiempo después $\mathrm{Q}$ fue usada y transformada "malintencionadamente" por Marcos, y más tarde por Mt y Lc181.

\section{Los otros cuatro movimientos de Jesús}

Frente a la riqueza y amplitud de la descripción del grupo, palidecen los otros cuatro movimientos de Jesús. Su existencia se debe a inferencias y a un material escaso y poco diferenciado.

Al primer grupo de estos cuatro le llama las Columnas de Jerusalén. Infiere su existencia de Gal 1,18;2,2.6. La noticia que da Pablo no debe suponerse como histórica. Lo que Pablo intenta es conectar el cristianismo al que él se convirtió con la capital del fariseísmo. Es Lucas quien también insiste en la existencia de esta iglesia en un momento, por cierto, en que ese cristianismo ya no vivía allí; de esta manera ha surgido la tradición sobre la iglesia de Jerusalén que supone buen número de leyendas: la estancia de Pedro, las apariciones, el sepulcro vacío, etc. Según Pablo, en contra de lo que él piensa, este grupo es fiel a la ley, a la circuncisión, a las leyes alimenticias y a la comensalidad cerrada. Nada, al parecer, separa a este movimiento de cualquier otro grupo judío si no es su referencia a Jesús. El origen de la comunidad puede remontar a una breve estancia de Jesús en Jerusalén y a su muerte ocurrida aquí por motivos desconocidos. La mitologización también prendió en este grupo imaginando alguna relación entre la predicación galilea de Jesús y el destino trágico de Jesús en Jerusalén. Que después se trasladaran a Jerusalén proviene de la importancia que ellos se dan. Su ideología es típica de una

180. Puede Mack encontrar testificada esta aproximación a la ley en el dicho de Q 16,17 ("es más fácil que pasen el cielo y la tierra que no que caiga un ápice de la ley"). Es curioso que atribuya también a Q3 la prohibición del divorcio, que va contra la ley.

181. El Evangelio, 185. 
secta judía que cultiva valores hasídicos. Quizá en Jerusalén no tenían otra posibilidad de subsistir sino es entendiendo el reino de Dios como una reforma del templo y de las instituciones judías. Como era una secta judeocristiana, no debió considerar a Jesús como ser divino. Se limitaban a interpretar la ley apelando a la autoridad de Jesús ${ }^{182}$.

Un segundo grupo muy relacionado con el anterior es el llamado la familia de Jesús. Un miembro de las "Columnas de Jerusalén" era Santiago, hermano del Señor. Por fuentes posteriores se sabe que en Transjordania se formó un grupo judeocristiano llamado nazarenos muy relacionado con los ebionitas. A juzgar por Q, que rebaja el papel de la familia de Jesús, Mack supone que tuvo conflictos con la comunidad de Q sobre el tema de la autoridad. Para ellos debió ser un orgullo tener relación familiar con un personaje que entretanto se había hecho tan famoso. Su ideología debió ser de tendencia hasídica ${ }^{183}$.

Congregación de Israel llama Mack al tercer movimiento de Jesús. Su existencia la basa en la hipotética fuente de narraciones de milagros usada para componer Mc y Jn. El hecho de que formen colección y de que se sorprendan semejanzas llamativas entre los milagros de ambos evangelios favorece la afirmación de la existencia de un grupo que los cultiva con mimo. Además presentan a un Jesús con un rostro suficientemente distinto y particular. Los milagros atañen a individuos socialmente marginados. Ello permite inferir a la ideología del grupo: recoger candidatos eliminando las barreras que la ley imponía. Las alusiones a Moisés y Elías (los milagros se inspiran en las historias de ambos personajes) es un recurso hábil que les permitía considerarse como los continuadores de la tradición de Israel e incluso sus verdaderos herederos. De esta manera los milagros fueron el punto de partida que sirvió para reforzar el papel de Jesús como fundador. Tal mitologización no suponía que Jesús fuera considerado divino. Esta exaltación de Jesús es perfectamente comprensible si se tiene en cuenta la idea helenista del hombre divino. La mitologización de esta manera responde a los intereses del grupo que busca la propia identidad social: reivindicar la historia épica de Israel fue el recurso más fácil 184.

182. A Myth, 88-90.

183. A Myth, 90-91.

184. A Myth, 91-93. 
Finalmente el quinto grupo de los movimientos de Jesús recibe el nombre de Reforma sinagogal. Deduce su existencia de los apotegmas que Marcos conserva, pero en estado muy elaborado. En ellos los escribas y fariseos desafían a Jesús con preguntas sobre temas discutidos: observancia del sábado, ley de la pureza, ayuno, etc. Jesús sale triunfante, pero lo que dice solamente vale para los que admitan su autoridad, por lo que estas historias suponen un grupo de seguidores de Jesús. Es de suponer que el grupo se entendía como un grupo de reforma judía. Se vio envuelto en acalorados conflictos con los fariseos intentando reformar la sinagoga. Los fariseos tenían todas las de ganar por tradición y argumentos. Para el grupo sólo Jesús tenía autoridad, pero esta falta de racionalidad necesitaba una convalidación mayor. Esto es lo que hará Marcos.

Como los dichos, apotegmas, milagros, etc. presentan una figura diferente de Jesús, Mack supone que los grupos y movimientos eran distintos. Le resulta difícil imaginar que un exorcista que expulsa demonios pueda ser al mismo tiempo un estupendo narrador de parábolas ${ }^{185}$. No obstante, no serían raros los intercambios y cierta interacción entre los grupos en determinado momento de su historia. La misma fuente $\mathrm{Q}$ a un cierto nivel recoge historias de milagros.

\section{3. Los cultos de Cristo}

Este es el segundo gran grupo del cristianismo primitivo. La información procede sobre todo de Pablo. Al principio era un movimiento de Jesús como los demás, pero como estaban en Antioquía, gran mar de la cultura helenista, innovaciones profundas no tardaron en aparecer. El movimiento contracultural e igualitario consistente en la comensalidad abierta resultó atractivo para judíos y gentiles. Esta comunidad mixta proveyó un contexto estimulante en donde el pensamiento cínico y la mitología griega pudieron mezclarse con las ideas del grupo de Jesús. Las reuniones de mesa tomaron pronto tonos rituales a semejanza de las religiones mistéricas. Surgió una mitología acerca de Jesús como ser divino teniendo como núcleo la resurrección. Mack mismo reconoce que el mayor desafío con el que se encuentra es explicar el fenómeno a todas luces sorprendente de que de un sabio cínico muerto reciente-

185. A Myth, 55. 
mente se le imaginara hijo de Dios y figura trascendente ${ }^{186}$. Desde luego Antioquía se prestaba bastante bien para la empresa, porque sólo aquí se entiende esta mezcla de mitos griegos e ideales judíos ${ }^{187}$. El salto lo trata de explicar recurriendo a un elemento del culto de Cristo, a saber, la noción de que Cristo murió por nosotros. El origen de esta idea no hay que buscarla en el mundo judío, donde no existe, sino en el mundo griego, donde existe una tradición de ensalzar la muerte noble ${ }^{188}$. En este tema Mack depende de D. Seeley quien defiende que la comprensión paulina de la muerte de Jesús no tiene origen judío sino que proviene de la noción helenista del mártir que muere por su honor y obediencia, en la idea de la muerte noble del héroe que da la vida por la ciudad ${ }^{189}$. Después el esquema se extendió a los reyes, atletas y filósofos, quienes morían por sus ideales a manos de un tirano. Este mito griego sufrió una adaptación en el judaísmo helenista, por ejemplo, en 4 Macabeos y Sabiduría. Conforme a este cuento, el justo, acusado y perseguido injustamente es asesinado. Su reivindicación tendrá lugar así después de su muerte mediante la inmortalidad o la resurrección ${ }^{190}$. Con estas ideas en el aire, no debe extrañar la mitificación de la figura de Jesús.

Naturalmente tuvieron que hacerse otros ajustes. Por ejemplo, hubo que imaginarse la causa por la que murió Jesús. Los mártires mueren por instituciones o lealtades ya existentes. Como la finalidad del mito era racionalizar la formación social que ya estaba en marcha, resultó fácil imaginar que Jesús intentó esta nueva sociedad formada por judíos y gentiles, que él habia vivido conforme a este plan y que había muerto por esta causa. Los judíos,que necesitaban entender esto en sus propias categorías, introdujeron el lenguaje de la

186. A Myth, 101 .

187. No se entiende bien que Mack recurra a Antioquía ("cuanto más lejos de Galilea, mejor", A Myth p.101) como lugar propicio donde surge el mito de Cristo, si la Galilea estaba profundamente helenizada. Conviene comparar estas dos afirmaciones: "Galilee was in fact an epitome of Hellenistic culture on the eve of the Roman era"(p. 66) y " Antioch was a great seat of Hellenistic culture" (p.101).

188. A Myth, 103-107; El Evangelio, 224-225.

189. D. SEELEY, The Noble Death. Graeco-Roman Martyrology and Paul's Concept of salvation (JSNT 28). Sheffield 1990.

190. Pensar que la pasión y muerte de Jesús fue compuesta siguiendo el modelo de la tradición griega de la muerte por una causa noble, resulta un tanto incomprensible. Celso (2.42) negaba que la muerte de Jesús pudiera presentarse como ejemplo, ya que en Getsemaní lejos de mostrar serenidad, coraje y resolución aparece preso del miedo y cobardía. Sin duda alguna Mc (para Mack) o el relato premarcano (para otros) no siguieron la tradición pagana. Por otra parte las alusiones al A.T. especialmente a Isa 53 y a los salmos son tan numerosas que no es difícil averiguar dónde se inspiró el relato. Sobre esto véase Collins, A. Yarbro,"From Noble Death to Crucified Messiah": NTS 40(1994)481-503. 
justificación. Lo que hacía a los gentiles y judíos justos eran formar parte de la nueva sociedad. De esta manera la función del mito es justificar la diversa composición étnica del grupo, conforme a la teoría de la religión que tiene Mack ${ }^{191}$. Este mito era necesario para los creyentes helenistas. En su ambiente social, las enseñanzas aforísticas de Jesús no podían atraer excesivamente. Un mito era preciso para justificar la inclusión de los gentiles dentro de un grupo que reclamaba ser la representación de Israel. "Separados de la sinagoga, en medio de amasijo de ideas y necesitando justificación, los cristianos se decidieron por un evento en vez de por la enseñanza. El suceso fue, imaginado míticamente, la crucifixión y la resurrección" 192.

\section{4. El Evangelio de Marcos}

La creación de este evangelio es el punto decisivo en la evolución del cristianismo. Mack coloca a Marcos en la confluencia de todos los movimientos de Jesús con los cultos de Cristo, aunque él era miembro del movimiento de la reforma sinagogal. El es el verdadero artífice del cristianismo. "Si alguien quiere conocer el evangelio original, debe estudiar el modo en que Marcos fabricó su historia y determinar por qué la presentó así"193.

Marcos comenzó a coleccionar las tradiciones asociadas a los diversos grupos cristianos incluyendo $\mathrm{Q}^{194}$ y también las tradiciones totalmente diferentes de los cultos de Cristo. Marcos fue un scholar, lector y escritor de textos. Su evangelio no es una piadosa transmisión de una tradición venerada. Fue compuesto sobre el pupitre de un scholar en medio de multitud de textos y abierto a la discusión con otros intelectuales ${ }^{195}$. Todo el material que juzgó conveniente incluir fue fabricado por él en forma narrativa siguiendo el modelo literario de las biografías.

191. A Myth, 109-110.

192. A Myth, 121-122.

193. A Myth, 12.

194. Mack con algunos piensa que Mc conoció a Q. No son pocas las complicaciones en que se coloca con esta opinión. Es Marcos quien conoce a Q y de ahí toma la figura de Juan de quien suprime el discurso. Cabe preguntar ipor qué lo iba a suprimir, si uno de los objetivos de Marcos es "apocaliptizar" el mensaje cristiano?

195. A Myth, 321-2. 
¿Por qué hizo Marcos esto? Sencillamente para racionalizar la historia social del grupo de Jesús. El movimiento de Jesús fue un fracaso; en vez de renovar la sinagoga fue expulsado de ella ${ }^{196}$. Esto produjo una hostilidad creciente frente el mundo; por lo que el movimiento de Jesús fue adquiriendo un tono apocalíptico. Necesitaban justificar su existencia social. Marcos le proporcionó esta nueva autodefinición social.

Tuvo también motivos internos. El movimiento igualitario se dividió sobre temas importantes: quién tiene autoridad, o cómo la autoridad del fundador debía ser concebida. La división entre el movimiento de Jesús y el culto de Cristo minaba el mismo movimiento. El grupo se desintegraba debido a la pérdida de lealtades, diversidad de liderazgo y cristologías e ideologías competitivas. Para salvarlo había que hacer algo. El ambiente estaba maduro para que brotaran nuevas imaginaciones fantásticas y míticas.

Al estructurar el mito no como nueva revelación, sino como historia, proporciona una identidad al movimiento; lo que había sido la sociedad hasta entonces, lo había sido debido al plan divino. Los cristianos no habían nacido hace dos días, eran herederos y continuadores del Israel antiguo ${ }^{197}$.

Recurriendo a la mitología de los cultos de Cristo, Marcos introdujo a Jesús como Hijo de Dios. Para dar este paso se sirvió de la figura popular de la sabiduría personificada; así fue fácil pasar de un Jesús maestro a un Jesús agente divino en la historia de Israel. En la explicación de Mack la idea mitológica de la sabiduría juega un papel importante. La noción del Mesías en el judaísmo del segundo templo no fue frecuente. Era una de tantas figuras ideales, todas ellas asociadas a la sabiduría y todas tienen un fundamento sociológico. Son respuestas a problemas sociales y a cambios en una era de incertidumbre. Según Mack no sólo Q, sino también el Evangelio de Tomás, Pablo y los relatos primitivos de la pasión manifiestan maneras de razonar características de la sabiduría. Los cristianos hicieron lo que los judíos habían hecho:

196. Con excesiva frecuencia y muy alegremente habla Mack de las sinagogas y de la expulsión de los grupos cristianos de ellas. No se sabe con certeza si existían en el s. I. d. C. ni cuál era su carácter. El estado del debate lo ofrece H. A. MACKAY, "Ancient Synagogues: The Continuing Dialectic Between Two Mayor Views": Currents in Research: Biblical Studies 6(1998) 103-142.

197. Esta contraposición entre Q (y demás grupos de tradiciones que señala Mack) con los evangelios no tiene mucho sentido. Kloppenborg encuentra en Q tendencias historificantes orientadas hacia la forma de bios, de tal manera que el movimiento de Q a los Sinópticos fue un desarrollo interno. Si a ello se une el interés hacia la literatura bios entre los grecorromanos, no es sorprendente que se hayan escrito los evangelios. Cfr. L. W. HurTado, "The Gospel of Mark: evolutionary or revolutionary Document?: JSNT 40(1990)15-32. 
responder a los problemas mediante figuras ideales. La diferencia está en que los cristianos localizaron su idealización en una persona histórica.

Otro paso importe fue la introducción de la apocalíptica. Sirviéndose de las visiones apocalípticas del último estadio de Q, Marcos identificó a Jesús con el Hijo del Hombre. De esta manera ya tenemos el Juez final. Con estas credenciales, los apotegmas de Jesús ya no son crítica social o exhortaciones, sino que se convirtieron en revelación divina. Para reforzar este punto más claramente, Marcos recogió las historias de milagros y las mezcló con los apotegmas. De este modo revistió a Jesús de una autoridad sobrehumana bajo la cual la comunidad podía unirse. Convirtió su sabiduría de estilo cínico que invitaba sencillamente a ver las cosas de otra manera en una sabiduría que se impone y ordena. Al mismo tiempo reimaginó la historia. Mediante los apotegmas Marcos presenta a Jesús en conflicto primero con las autoridades sinagogales, después con los jefes del Templo. La impresión que surge de la narración es que hubo una masiva conspiración de todos contra Jesús. Y ello se debe a que los judíos no quieren aceptar la autoridad de Jesús. Este, en cambio, no es el culpable, puesto que es el Hijo de Dios que viene a implantar el reino de Dios. De esta manera fueron los fariseos y no Jesús quien inició la violencia. Con ello el conflicto que los cristianos tienen en su tiempo con la sinagoga fue proyectado al mito de origen y presentado como causa de la muerte de Jesús en conflicto con los judíos. Esto no tiene nada que ver con la historia de Jesús, sino con el movimiento de Jesús al que pertenecía Marcos. Para llevar a cabo la justificación social necesaria, el sabio cínico igualitario fue comercializado como un juez soberano imperial que gobierna por "fiat" 198.

Este cambio de imagen del fundador provocó un cambio de la autocomprensión de la comunidad. La narrativa apocalíptica sepultó el alma del movimiento de Jesús original.

Hemos dicho que Mc disponía de un pupitre lleno de papeles, pero lo que no tuvo era un relato de la pasión. Habiendo hecho una lectura apocalíptica del reino de Dios y habiendo presentado a los adversarios de Jesús conforme a la épica tomada del A. T., Mc da un paso más: une la crucifixión de Jesús con la destrucción de Jerusalén; producto todo ello de la expulsión del grupo cristiano de la sinagoga ${ }^{199}$. De esta manera se montó el mito más peligroso, el "mito de la inocencia". Mc unió el inocente (Jesús) y la comunidad justa (los 
cristianos). Pero la construcción de la víctima inocente lleva consigo la creación del culpable, el pueblo judío, cuya ciudad es destruida por no aceptar al hijo de Dios. La unión del poder y de la inocencia en Jesús: he ahí la atrevida construcción de Marcos, responsable en gran parte de la mayor parte de las enfermedades de Occidente y especialmente de la cultura americana ${ }^{200}$, pues nace aquí la mentalidad "nosotros-ellos", donde nosotros somos inocentes y Dios está de nuestra parte. Este es legado del mito de la inocencia de Marcos. Mack no solo descubre el propósito de Marcos, sino las perniciosas consecuencias de este mito inocente en el s. XX. Debido a Marcos los occidentales identifican el poder e inocencia en la misma figura. Decididamente "el mito de Marcos ya no es buena noticia"201.

\section{5. Jesús cínico}

Mack dedica poco tiempo a estudiar a Jesús, dado que su intento es exponer los orígenes del cristianismo junto con su teoría de la religión. Dada su manera de hablar de la mitologización creciente, apenas podría evitar el levantar un muro entre el Jesús histórico y el cristianismo difícil de atravesar. Tiene tentaciones de ello. De hecho llega a veces a decir que sólo sabemos que fue crucificado. No obstante, desvela la figura de Jesús presentándola como un sabio cínico, totalmente helenizado. Considera tres elementos como importantes para definir el tipo social al que pertenece Jesús: su sabiduría aforística, su crítica social y el ambiente helenista de la Galilea.

Prescindiendo de éste último que da por sentado, se detiene en los dos primeros. El modo de hablar con aforismos chispeantes y el contenido contracultural de los mismos le asemejan a un cínico, pero no un intelectual. El estilo de la crítica, vago y desconfiado concuerda con la postura cínica ${ }^{202}$. No pertenecía a un cinismo ascético, sino que se le recordó por pertenecer a la corriente hedonista ("hedonistic variety"203). No tiene nada de profeta, ni habla nunca de escatología o apocalíptica ni le interesaron nunca las tradiciones judías. La hipótesis cínica gana en credibilidad a medida que la visión de Jesús como profeta apocalíptico se reconoce como problemática204.

200. A Myth, 368-376.

201. A Myth, 372.

202. A Myth, 66-68.

203. A Myth, 188. 
Ultimamente suaviza un tanto su postura; desde luego, sigue manteniendo el cinismo de Q1 pero no está seguro de que el estilo de vida cínico de este movimiento de Jesús refleje el estilo de vida del Jesús histórico ${ }^{205}$.

Los chrias de la fuente $\mathrm{Q}$ y los apotegmas de Marcos constituyen la base argumentativa para Mack. Los chrias existentes en el evangelio, si se limpian, son notablemente parecidos a los cínicos. Tal como están hoy reflejan máximas éticas que uno encuentra en los dichos sapienciales convencionales. Es necesario una labor de crítica para recuperar la forma primitiva. Cuando se ha hecho esto, los chrias recuperados transmiten una lógica e inteligencia similar a la que los antiguos cínicos empleaban para responder a sus contrincantes que trataban de sorprenderles en incongruencias dado su modo de vida no convencional. En todo caso Jesús es una figura opaca; solo unos 17 chrias atribuye Mack al primer estrato de $\mathrm{Q}^{206}$. Y aunque intente presentar estos dichos como mordaces, él mismo reconoce que no son brillantes, incluso pueden parecer como perogrulladas ${ }^{207}$. El Jesús de Mack sería un cínico de poca calidad. Este sería el resumen de la conducta cínica y Q1: vivir naturalmente, no dejarse conducir por las reglas sociales y no preocuparse. Merece la pena guardar el sentido personal de la integridad.

En realidad apenas sorprende algún atisbo religioso en Jesús. Evidentemente se ve obligado a dibujarle con algún tono religioso, puesto que el reino de Dios del que habla lleva consigo la fe en Dios; el énfasis en Dios como dominador del reino le da una nota de seriedad no habitual en el mundo helenista; además sus seguidores lo entendieron conforme a las tradiciones judías ${ }^{208}$. Pero fuera de esto nada separa a Jesús de un cínico incrédulo. Su piedad debe atribuirse más al hecho accidental de ser judío que a un compromiso personal. Por supuesto niega cualquier lazo de unión histórica entre Jesús y las tradiciones taumatúrgicas y milagreras 209 .

204. A Myth, 69, nota 11.

205. Who Wrote the New Testament. The Making of Christian Myth. San Francisco 1995, 45-46.

206. El Evangelio, 122-123.

207. El Evangelio, 121.

208. A Myth, 73-74.

209. La imagen de Jesús dibujada por Mack es muy parecida a la que se imagina R. W. Funk, fundador y máximo dirigente del Jesus Seminar. Para éste Jesús fue un sabio "secular, irreligioso, irreverente e impío". La época moderna desmitificada no necesita un Jesús Pascual, o Jesús objeto de fe, que fue una idolatría perpetrada por los primeros creyentes. Lo 
La poca importancia de Jesús para Mack es perfectamente comprensible; es lo que su teoría de la religión necesita. Según él, la búsqueda del Jesús histórico ha sido realizada basándose en el hecho de que existió un origen singular y extraordinario del cristianismo y una persona única tras la mitología del N.T. Los escrituristas buscan un suceso singular (sus palabras, sus acciones, su muerte, su resurrección), sin darse cuenta de que estos elementos no son más que cifras para presentar una milagro inimaginable que está más allá de cualquier interpretación. En realidad no es más que un recurso retórico para evocar el mito de Cristo sin explicarlo. Para Mack debe quedar claro que la búsqueda de lo único es una búsqueda errada. La noción de un punto de origen singular no es una categoría de la ciencia académica, sino un artículo de la fe derivada de la mitología cristiana ${ }^{210}$. Por tanto para explicar el origen del cristianismo no hace falta recurrir a Jesús. Lo que hay que explicar es la actividad mitificadora creativa de los cristianos. En el origen del cristianismo no está la memoria o el recuerdo, sino la experiencia social como causa para la actividad imaginativa y la producción literaria211.

\section{6. Un ensayo con bastantes cosas antiguas}

Nadie puede negar la ambición del intento, puntos de vista perspicaces y brillantez de la exposición, aunque el lector hubiera agradecido que no fuera tan repetitivo. La novedad del enfoque fácilmente se le concede. Sin embargo, al querer presentar una visión tan global, amplia y totalizante, necesariamente ha de recurrir a intuiciones y reconstrucciones rebuscadas para que cumplan lo que se espera de ellas. De esta manera las hipótesis se van multiplicando, con lo que el cuadro general se hace cada vez más improbable.

El libro confronta al lector con dos tareas: la exegética y la hermenéutica. Se leen y se comentan textos de una determinada manera, pero sobre todo se interpretan desde una óptica especial, que se presenta como objetiva, pero el lector deberá ponderar qué valor tiene en este caso el término. ¿Objetivo se confunde con subjetivo? Construir una vida de Jesús es tarea personal; cada generación hace esta labor e incluso cada persona. La historia de la

que necesitamos es un contador de parábolas, que es lo que fue; los puntos de vista de Jesús deben ser corregidos evidentemente porque conocemos mejor la realidad del mundo (Honest to Jesus: Jesus for a New Millenium. San Francisco 1996, 297-314).

210. A Myth, 8 .

211. A Myth, 15. 
recepción del evangelio de Marcos demuestra que ha inspirado otras lecturas y ha servido para otras cosas y no precisamente para justificar el holocausto.

Prescindiendo de la idea de religión que subyace en toda la interpretación, quisiera fijarme en un punto que es propio de la investigación americana del Jesús histórico. En la obra The Five Gospels212 puede leerse que los seguidores de Jesús no entendieron bien a su maestro y cuando Jesús ya no estaba con ellos volvieron a los puntos de vista escatológicos de Juan Bautista. Por tanto la búsqueda del Jesús histórico es rescatarle de la construcción teológica inventada por sus seguidores.

Mack se adhiere a estas mismas ideas cuando afirma que Marcos no entendió las parábolas que en labios de Jesús presentaban una crítica aforística del mundo o una invitación a ver las cosas de diferente manera ${ }^{213}$. No es raro encontrar textos de esta guisa en su libro.

¿Es legítima esta posición? Hemos recibido varias interpretaciones de Jesús: Q, Marcos, Tomás, Pablo, etc. Aunque en $\mathrm{Q}$ o en Tomás se distingan estratos, incluso los más antiguos ya son interpretaciones interesadas. Si se recogen o se recuerdan las tradiciones, siempre se trata de un proceso selectivo, interpretado desde la realidad actual, porque se consideran interesantes para sus seguidores; la memoria existe cuando se echa mano de ella. No es posible alcanzar la tradición anterior fuera de su contextualización, o las palabras de Jesús independientemente de su transmisión.

Mack, Crossan y en general el Jesus Seminar creen que desde fuera del texto, desde las ciencias humanas (antropología, sociología, etc.), ciencias pretendidamente neutrales puede alcanzarse una historia anterior a la confesional, puede llegarse a un "texto neutro" contra el texto actual.

Ese pretendido punto "cero", ese estado neutral, ¿es tan objetivo como ellos lo pretenden? ¿Las ciencias humanas son tan objetivas? Las ciencias

212. "Jesus' followers did not grasp the subtleties of his position and reverted, once Jesus was not there to remind them, to the view they had learned from the John the Baptist...The Jesus of the Gospels is an imaginative theological construct, into which has been wowen traces of that enigmatic sage from Nazareth- traces that cry out for recognition and liberation from the firm grip of those whose faith overpowered their memories. The search for the authentic words of Jesus is a search for the forgotten Jesus"(R.W. FunK y otros, The Five Gospels. The Search for the Authentic Words of Jesus. New York 1993,4.

213. "Neither did Mark understand the parables spoken at the beginning to have offered an aphoristic critique of Jesus' word, or a parabolic invitation to imagine things differently and thus make a difference then" $(A M y t h, 170)$. 
humanas proporcionan datos que hay que traducir en un discurso. El relato histórico, sociológico o antropológico es siempre interpretación. Por tanto presentar un relato al margen o contra el texto actual es posible, pero siempre será un dato interpretado, aun cuando los críticos se entiendan como libres de toda valoración y objetivos. La hermenéutica de la sospecha se ha aplicado a la historia de Jesús, no a la historia de los historiadores ${ }^{214}$. Bajo este punto de vista es ingenua esta pregunta de Mack:

"¿Y si la noción de un punto original singular y milagroso fuera reconocida por lo que fue, no una categoría de la investigación crítica, sino un artículo de la fe derivado de la mitología cristiana?"215.

La ingenuidad es pensar que la fe consiste sólo en la historia, o que la investigación histórica pueda suplantar la fe, o que la investigación histórica es objetiva y la fe es subjetiva. Las dos son interpretaciones de la realidad. Ese punto original (por ejemplo, la existencia de Jesús, su muerte, su mensaje, etc.) será un punto de la historia, pero sujeto a distintas interpretaciones.

Conviene también notar que este intento de saltar por encima de las fuentes traslada a estos autores a la Old Quest, concretamente a Reimarus. Es contraponer a Jesús los discípulos o la comunidad. Ello sólo se puede hacer creando una historia nueva; la que hay es diferente. Cuando se da por supuesto que los discípulos no entendieron al maestro o falsificaron la enseñanza se deja vía libre a la fantasía.

Esto nos advierte de que hay mucho viejo en la teoría de Mack. Por ejemplo, en la separación entre movimientos de Jesús y cultos de Cristo se observa la teoría de Bousset, así como en la supuesta influencia de las religiones mistéricas. Ya en su tiempo esta hipótesis, que ligaba la divinización de Jesús a la influencia de estas religiones, resultaba inaceptable dado que son del s. III y IV. Por su parte considerar al primer Jesús como no apocalíptico era común hasta los tiempos de Weiss y Schweitzer. El proyecto de Mack manifiesta muchas analogías con las vidas de Jesús del siglo pasado obsesionadas por recuperar una edad de oro no contaminada por la cristología, la apocalíptica, la Escritura y las disputas con el judaísmo ${ }^{216}$.

214. T. C. Oden, The Word of Life: Systematic Theology, Vol.2, citado por G. A. Boyd, Cynic Sage, 115.

215. "What if the notion of a single, miraculous point of origin was acknowledged for what it was, not a category of critical scholarship at all, but an article of faith derived from Christian mythology?" ( $A M y h t, 8)$.

216. Esta afinidad al Jesús de la teología liberal es frecuentemente citada. Véase W. H. KelBer, CBQ 52(1990)163 (Recensión de la obra de B. L. Mack); J. WeHNERT, "Festschriften und Sammelbände zum N. T.: TR 63 (1998)370. 
Por lo demás la improbabilidad de la hipótesis se manifiesta en múltiples puntos. Muchos cínicos hubo en la antigüedad; resulta que este cínico Jesús es el único que forma grupos (cosa desconocida entre los cínicos) y es el único venerado y al que se le mitifica. Decir que los procesos de identificación social del grupo producen los relatos, los mitos etc. deja sin contestar por qué solo ocurrió aquí este fenómeno.

La afabulación que se supone exige más tiempo para fabricarse. Y no lo hay. Mc escribe después del año 70, pero resulta que unos veinte años antes por lo menos, ya Pablo habla de Jesús como Hijo de Dios y Cristo. Siendo así las cosas, ¿se puede atribuir a Mc la iniciativa de unir en Jesús el poder y la inocencia?

Mack atribuye también a Marcos la introducción de la apocalíptica en el mito cristiano ${ }^{217}$. Resulta, sin embargo, que Pablo ya tiene un pensamiento apocalíptico claro veinte años antes. De dónde sacó Marcos esta teología permanece en el misterio, pues Mack, a pesar de las pruebas en contra, se imagina a la Galilea sin fervor apocalíptico alguno ni expectación mesiánica. El descuido de Pablo (personaje inestable y autoritario ${ }^{218}$ ) entre los miembros del Jesus Seminar es general. Para ellos Q se convierte en un punto de referencia absoluto; Pablo y el resto de las tradiciones evangélicas son marginadas.

El papel atribuido a Marcos es a todas luces increíble. En la teoría de Mack todos los cristianos están integrados en comunidades con sus tradiciones que inventan y cambian conforme a los procesos sociales; sin embargo, Marcos está en su pupitre fabricando una amalgama intelectual, como el secretario general de la ONU presenta ante el Consejo de Seguridad un documento fruto de un compromiso. ¿Cómo tal fabricación pudo haber sido creída por el grupo de Jesús durante la generación de Marcos? Por hipótesis esa comunidad hasta entonces vive teniendo otro punto de vista. ¿Cómo tal obra llena de elementos ajenos y extraños a las creencias mantenidas hasta entonces pudo adquirir autoridad, teniendo en cuenta que el autor del Evangelio era un Don Nadie (M. Hengel) ${ }^{219}$, convertido en aprendiz de brujo y "vicioso manipulador220?" A Marcos le puede consolar el hecho de que, en vez de escritor más bien rústico, Mack le convierte en un intelectual. Es más, ¿no le habrá convertido en un "mito?

217. A Myth, 328.

218. A Myth, 98.

219. G. A. Boyd, Cynic Sage or Son of God. Wheaton, 1995, 214.

220. A Myth, 295. 


\section{J. D. Crossan 221}

Crossan es un escritor prolífico. Es el único de los cuatro, de quien se ha traducido al español la obra más importante, al decir de Wright un "libro casi totalmente erróneo"222. La influencia de esta obra es considerable y más conocida que las obras de los autores anteriores.

\section{1. Metodología}

Es original en este aspecto. La expone en estos términos: "La metodología... se caracteriza por un triple proceso ternario: campaña, estrategia y táctica. La primera es llevada en tres frentes: "Uno macrocósmico, caracterizado por una antropología intercultural e intertemporal; otro mesocósmico que utiliza la historia helenística y grecorromana y un tercer nivel microcósmico que emplea la literatura que recoge los dichos y hechos, los relatos y anécdotas, confesiones e interpretaciones relativas a la figura de Jesús"223. Evidentemente el interesado directamente en Jesús y no en el ambiente social o político, prestará atención a la tercera parte.

Comienza con el análisis de los datos textuales. En primer lugar, hace el inventario de todas las fuentes y textos, tanto canónicos como no canónicos. Luego los coloca en su lugar dentro de una serie cronológica. Es lo que llama estratificación. Divide las fuentes en cuatro etapas cronológicas: textos entre los años 30-60; 60-80, 80-120, y 120-150. El último paso es la atestación, es decir, las veces que cada dato referente a Jesús ocurre en fuentes independientes. Concretamente distingue cuatro categorías: datos atestiguados una sola vez, datos atestiguados dos veces independientemente, los atestiguados tres veces y finalmente los atestiguados más de tres veces siempre en fuentes independientes.

La interpretación de los datos es la que cabría esperar. Hay que dar importancia a la secuencia de estratos: cuanto más antiguo es un estrato, más probabilidades hay de que conserve datos originales. El segundo principio atañe a la jerarquía de la atestación: cuantas más atestiguaciones independientes haya de un dato, más probabilidades hay de su originalidad. Pone

221. Jesús: Vida de un campesino judío. Barcelona 1994; ID. , Jesús: Una Biografía revolucionaria. Barcelona 1996. Este libro es un resumen vulgarizador del primero.

222. N. T. WRIGHT, Christian Origins and the Question of God. 2. Jesus and the Victory of God. Minneapolis 1996, 44.

223. Jesus, 25. 
entre paréntesis todos los datos que estén atestiguados una sola vez, aunque aparezca en un documento del primer estrato. No obstante reconoce que al menos para el primer estrato cabe pensar que todo es original, a menos que se pueda demostrar lo contrario 224 . Conforme a estas premisas encuentra 131 dichos que superan las condiciones impuestas: pertenencia al primer estrato y atestación plural.

\section{2. Resultados}

Dada la situación y los tipos sociales existentes en el mundo mediterráneo del s. I, Crossan llega a la conclusión que Jesús cae dentro de estas categorías: Es un judío, campesino, mago y cínico.

En primer lugar es un judio, pero dentro del judaísmo inclusivo. Con este término Crossan quiere decir que pertenece a un judaísmo abierto a otras influencias no judías. Crossan no heleniza a Jesús tanto como Mack o Vaage. Al contrario le incluye dentro de la cultura y tradiciones judías, aunque este encuadre no le conceda a Jesús una nota específicamente religiosa.

Su carácter campesino es indudable. Con ello quiere afirmar que no pertenece a la élite culta y sofisticada que caracteriza por ejemplo a Filón de Alejandría. Jesús está dentro de la cultura popular, oral y campesina. Lo que caracteriza a estas poblaciones es la opresión social y económica. Para ellos las cosas buenas de la vida son siempre escasas, no sólo porque existen en cantidad limitada, sino porque nunca está en sus manos la posibilidad de incrementarlas. Esto sencillamente quiere decir que se trata de una sociedad carente de movilidad social; además es una sociedad muy mediatizada por el clientelismo, el honor y la vergüenza. En esta situación es normal que la protesta y el descontento encuentren su terreno abonado. Las protestas son frecuentes durante el tiempo de Jesús. Crossan dibuja a un Jesús muy consciente de esta opresión social y económica e intérprete de esta situación de desajuste social225, más desde luego que de la situación religiosa de entonces.

Parece más novedoso el calificativo de mago dado a Jesús. Se refiere evidentemente a su actividad milagrera, que para Crossan es innegable. Entien-

224. Ib. 29

225. Crossan no llega a dibujar a Jesus con los rasgos de un agitador social, como hace $\mathrm{R}$. A. HorSLEY, Jesus and the Spiral of Violence: Popular Jewish Resistance in Roman Palestine. San Francisco 1987. 
de esta actividad antropológicamente, viendo a Jesús como uno de los sanadores o chamanes de las culturas primitivas. Para Crossan el término mago no es peyorativo, sino que le sirve "para describir a la persona capaz de hacer presentes los poderes divinos directamente a través de un milagro personal y no indirectamente a través de un rito colectivo" o dicho de otro modo "es un acceso personal e individual, no colectivo e institucional, al monopolio de los poderes divinos o al control de éstos"226. Por medio de esta actividad Jesús ejerce su protesta eminentemente religiosa. En contra del poder divino controlado y mediatizado por los líderes religiosos, Jesús reclama poderes propios mediante su actividad taumatúrgica. Es una protesta religiosa que pone en entredicho los poderes exclusivos del templo y del sacerdocio.

Los milagros de Jesús tienen otra finalidad: ser un arma importante del movimiento social que intentaba inaugurar entre los campesinos. Jesús envió los discípulos para realizar milagros de curación y exorcismo y, a cambio, eran acogidos en la casa y en la mesa. "En esto radica, en mi opinión, la clave del movimiento creado originalmente por Jesús, en el igualitarismo compartido de los recursos espirituales y materiales"227. Sin los exorcismos y curaciones "la visión del reino que tenía Jesús no sería más que un sueño extático sin repercusiones sociales inmediatas 228 .

Curiosamente esta actividad no cínica de Jesús no conduce a Crossan a dotar a Jesús de una visión judía de la vida. A primera vista si se admiten los exorcismos, lo más propio sería acudir para su explicación al mundo judío, donde hay una visión dualista de la vida. Cree posible compaginar actividad milagrera y cinismo porque integra los milagros como parte de la visión contracultural de la sociedad.

Para ello distingue afección ("disease" = patologías orgánicas) y el mal ("illness" = efectos psicosociales y culturales de la enfermedad). Las curaciones de Jesús se realizan en el segundo ámbito ${ }^{229}$. Jesús no curó físicamente, sino que eliminó las implicaciones sociales de la enfermedad, simbolizando de esta manera su visión igualitaria. En esto reside el éxito obtenido por Jesús y sus misioneros 230 .

226. Vida, 178

227. Vida, 393

228. Vida, 383-4.

229. Vida, 388-90.

230. Ante esta explicación M. Borg se pregunta: " ¿Curar la 'illness' sin curar la "disease" tiene sentido en una sociedad campesina?. ¿Se sentiría impresionado alguien porque uno le dijera que su enfermedad estaba curada, cuando las condiciones físicas seguían siendo las mismas?" (Jesus in contemporary Scholarship. Valley Forge 1994, 43, nota 88). 


\section{3. El Cinismo de Jesús según Crossan}

Finalmente Jesús era cínico. Yo no sabría decir si para Crossan Jesús es más judío que cínico o al revés, en cuanto a la visión del mundo. El cinismo le provee a Jesús con una nota contracultural, desde luego, pero también hay algo más importante. Crossan deriva e interpreta el contenido y la doctrina de Jesús y sus modelos sociales del helenismo. El argumento que le inclina a optar por el cinismo de Jesús es el concepto de reino de Dios que entiende de manera sapiencial, apoyándose en Mack que a su vez se apoya en la filosofía popular cínica231. El Reino que Jesús proclama es de carácter sapiencial: (El reino) "mira al presente, no al futuro, y postula cómo podría ser la vida aquí y ahora, en el marco de un reino divino siempre accesible. Se entra en ese Reino a través de la sabiduría o la bondad, por medio de la virtud, justicia o la libertad"232. A esta conclusión llega, por dos razones, en primer lugar porque la otra alternativa, un reino apocalíptico no cuadra bien con el contexto social y campesino de Jesús. El reino apocalíptico es más propio de la literatura de la élite social. Además encuentra que en los diez testimonios sobre el reino de Dios que le merecen crédito, observa que el reino de Dios sapiencial es preeminente. La oración del Padre Nuestro, que para Crossan no es de Jesús, viene a confirmar el carácter sapiencial o ético del reino. Este reino es el que se pide en esta oración, que consiste en el pan material necesario para la subsistencia. El mutuo perdón de las deudas debe interpretarse como condonación de las deudas monetarias. El reino de Dios aportaba el alivio de estas dos cargas 233 .

Basa además su hipótesis de Jesús cínico en el ingenio aforístico y socialmente subversivo y en los paralelos entre Q (sermón de misión) y los itinerantes cínicos.

Esto no quiere decir que no vea distinción entre ambos. Jesús actúa en ambiente rural, los cínicos en ambiente urbano. Los cínicos usan una bolsa, Jesús se la prohibe (dando así importancia a la comensalidad y dependencia). Jesús hizo curaciones y exorcismos, mientras que los cínicos, no. A pesar de

231. El Evangelio perdido, 134-137.

232. Vida, 340 .

233. Crossan no indica cómo entiende la petición siguiente sobre la liberación de la tentación. De todas maneras, uno esperaría que si lo que se pide en el Padre Nuestro es la condonación de las deudas monetarias, en vez de pedírselo a Dios, ya podían pedirlo a los demás, máxime si se tiene cuenta que los discípulos de Jesús y Jesús mismo no eran especialmente religiosos. La petición principal del Padre nuestro, ¿no será la relación filial entre el que pide y Dios?, como anota Ch. M. TuCKeTT, $Q$ and the History of Early Christianity, 153. 
todo, dada la sintonía entre las enseñanzas, Crossan cree que Jesús cae en la categoría de un cínico.

Jesús para él no está imbuido por una visión religiosa. Los dogmas del judaísmo como el monoteísmo, elección, escatología juegan escaso papel; en su lugar es un Jesús laico, motivado por factores socioeconómicos.

El Jesús de Crossan puede dibujarse así: Un campesino cínico, judío, mago, proclamador de un igualitarismo radical en una cultura regida por brokers y jerarquías. Lo proclamó mediante aforismos y parábolas, lo simbolizó en su magia, y lo practicó mediante la comensalidad abierta ${ }^{234}$. Sus primeros seguidores le vieron como a un maestro con una visión revolucionaria de la vida y fundador de la comunidad igualitaria y abierta. Por sus mentes nunca pasó la idea de atribuirle cualidades sobrenaturales. Tampoco creyeron que hubiera reclamado para sí pretensiones divinas. No le dieron ningún sentido especial a su muerte, de la que, por otra parte, apenas supieron nada. Por supuesto tampoco tuvieron conocimiento alguno de la resurrección. No obstante, alguna fe hay que atribuir a sus seguidores puesto que se adhirieron a él. Cabe pensar que lo que les atrajo fue vivir conforme a la sabiduría contracultural, que había predicado y practicado su maestro235.

\section{4. ¿El libro más importante sobre el Jesús histórico desde A. Schweizer?}

Así ha sido saludado236. Sin duda es uno de los libros referentes a Jesús que más ha llamado la atención.

Ha querido hacer una obra objetiva. Crossan ha reflexionado sobre el método que se debe emplear en la investigación del Jesús histórico. Consciente de la alta subjetividad (que personalmente pienso no es mayor que en el resto de las ciencias humanas) intenta que la investigación se reali-

234. La idea de la comensalidad abierta es un concepto básico en la obra de Crossan. Sin embargo, no hay alusión alguna a comidas comunitarias en Q. Nunca se dice en Q dónde enseñaba Jesús. Y esto es raro si la comensalidad era la ocasión de la enseñanza. La parábola del banquete a la que le da tanta importancia Crossan es un cuento, como él mismo reconoce ( $\mathrm{p}$. 310). Los demás siete complejos que cita Crossan no hablan de comer juntos. Tiene razón Horsley cuando afirma que la comensalidad sólo aparece en un apotegma de Mc 2, 15-17. Véase R. A. Horsley, "Q and Jesus; Assumptions, Approaches, and Analyses": Semeia 55(1992)203-4.

235. G. A. BOYD, Cynic Sage, 86.

236. M. BORG, Jesus in contemporary Scholarship. Valley Forge 1994, 33. 
ce objetivamente; por ello hace inventario de la tradición, distingue estratos, fuentes independientes, etc.

Sin embargo, su metodología está llena de interrogantes. Veamos por qué. Distingue cuatro etapas cronológicas o estratos: años 30-60, 60-80, 80-120 y 120-150. Es claro que la fijación de estas fechas es totalmente arbitraria y subjetiva y no puede fundarse sobre un hecho objetivo. Otros cortes cronológicos podían hacerse. Ahora bien, si es una decisión personal, habrá que preguntarse por qué se hace así.

Hay algo más. Asigna 13 fuentes a la primera etapa: cuatro cartas de Pablo (1 Tes, Gál, 1 Cor y Rom); cinco reconstrucciones hipotéticas: $1^{a}$ ed. del Evangelio de Tomás, un triple estrato de $Q$, una colección de milagros (detrás de los milagros de Mc y Jn), un guión apocalíptico (incorporado en Didaje XVI, 3-8 y Mt 24, 10-12), el evangelio de la Cruz (hoy incrustado en el Evangelio de Pedro). Tres son fragmentos de textos papiráceos: Egerton 2, el Papiro Viena G. 2325 y el papiro Oxyrhynchus 1224. Finalmente el evangelio de los Hebreos que es conocido únicamente por las citas de los Padres.

Excepto las cuatro cartas de Pablo, todas las demás obras citadas presentan problemas sobre su fecha y sobre su supuesta independencia respecto de la tradición sinóptica. Crossan asigna el evangelio de los hebreos a los años 50 y es independiente de los Sinópticos ${ }^{237}$. Esto es una pura conjetura. Cualquier fecha entre el 50 y 150 vale; por otra parte tiene tan escasa entidad que el mismo Crossan lo usa muy raramente.

El evangelio secreto de Marcos puede ser una "falsificación del s. XX"238. En todo caso es cortísimo (apenas 24 líneas), controvertido y es muy común afirmar su inutilidad para el Jesús histórico 239.

El Papiro Egerton ${ }^{240}$, contiene cuatro (o cinco) historias, para Crossan puede ser de los años 50 y ser fuente de Mc. Estas afirmaciones son puramente gratuitas. En realidad la mayoría piensa que es una mezcla de tradi-

237. Puede leerse lo esencial en A. de Santos Otero, Los Evangelios Apócrifos. $9^{\mathrm{a}}$ ed. Reimpresión. Madrid 1996, 29-47.

238. Así J. NEUSNER, "Who needs the 'Historical Jesus'?. An Essay-Review": Bulletin for Biblical Research 4(1994) 115.

239. E. BAMMEL, JSNT 4 (1979)69-76; F. NEIRYNCK, ETL 55(1979) 43-66; H. MERKEL 71(1974) 123-144; Q Quesnell, "The Mar Saba Clementine: A Question of Evidence": $C B Q$ 37 (1975)48-67; la réplica de M. Smith (el"descubridor" de este evangelio) en $C B Q$ 38(1976)196-199; y la contestación de QUESNELL, CBQ 38(1976)200-203.

240. A. de Santos Otero, Los Evangelios, 91-96. 
ciones sinópticas y joánicas del s. II ${ }^{241}$. Los otros dos trozos papiráceos (el Fragmento de Fayum y el Oxyrhinco 1224) son tan breves que no tienen consistencia alguna.

El evangelio de Pedro ${ }^{242}$ es tardío, pero para Crossan preserva en su interior un estrato que él llama evangelio de la Cruz que cree anterior y más antiguo que los evangelios sinópticos. La mayoría lo cree escrito alrededor de los años 150 y basado en los escritos canónicos 243

El evangelio de Tomás ${ }^{244}$ es el más interesante.y también el más discutido. Según Crossan la primera edición fue hecha posiblemente en Jerusalén en los años 50; la $2^{\mathrm{a}}$ edición es de los años 60 o 70 . Considera que pertenecen a la primera edición aquellos dichos atestiguados en otras fuentes, en la práctica en Q. El resto comprendería los dichos propios a este evangelio. A este respecto cabe decir dos cosas. El mismo Crossan considera que esta estratificación es "tosca" (p. 490). Por otra parte la fecha atribuida al primer estrato es típica de Crossan que ya sabemos es partidario de asignar una alta antigüedad a las fuentes no canónicas. Fuera del Jesus Seminar es normal fechar el evangelio más tardíamente, hacia fines del s. I e incluso en el s. II245.

A primera vista las fuentes parecían numerosas; observado de cerca el panorama es desalentador. En la práctica el Jesús de Crossan es una reconstrucción basada en Tomás1, Q ${ }^{246}$ y el Evangelio de la Cruz. En realidad todas ellas son reconstrucciones altamente hipotéticas y su datación es voluntarista. Si, por ejemplo, en vez de fechar Q1 en los años 50 se coloca en los 60 (cosa muy posible), un tercio del componente del primer estrato pasaría al segundo. La figura de Jesús sufriría un grave quebranto247. En definitiva, la subjeti-

241. J. H. Charlesworth-C.A. Evans, "Jesus in the Agrapha and Apocryphal Gospels": B. Chilton-C. A. Evans (ed.), Studying, 525. Ultimamente K. ERlemann ("Papyrus Egerton 2:'Missing Link' zwischen synoptischer und johanneischer Tradition": NTS 42,1996, 12-34) afirma que proviene de una comunidad judeo-cristiana y cronológicamente debe situarse entre los Sinópticos y Juan.

242. A. de SAntos Otero, Los Evangelios, 369-387.

243. M. RodríGuez Ruíz, "El Evangelio de Pedro: ¿Un desafío a los evangelios canónicos? : Estudios Bíblicos 46(1988)497-528

244. A. de Santos Otero, Los Evangelios, 678-705; M. Alcalá, El Evangelio copto de Tomás. Salamanca 1989.

245. R. VALANTASIS (The Gospel of Thomas. London and New York 1997,12-21) que trata de manera profunda el tema de la fecha, le coloca durante la primera década del s. II (100-110 d. c.) junto el Evangelio de Juan y las Cartas de S. Ignacio.

246. En la práctica sólo es tenida en cuenta Q1, porque es sapiencial.

247. D. C. Allison, Jesus of Nazaret: Millenarian Profet. Minneapolis 1998, 16. 
vidad que Crossan había querido expulsar por la puerta, se le ha colado por la ventana.

El Jesús de Crossan depende prácticamente de la opinión muy personal que tiene de la antigüedad de las fuentes. Como él ha retado a que no se le critique solamente, sino que se presente otra fijación de las fuentes, D. C. Allison ha recogido el guante y establece otra serie cronológica de las fuentes y otros plazos más acorde con la opinión común, y naturalmente ha extraído otra imagen de Jesús. Lo decimos no porque estemos de acuerdo con este último bosquejo, sino para demostrar que la subjetividad en este campo es grande.

Otro punto quisiera tocar. Es claro que los tres miembros del Jesus Seminar helenizan la figura de Jesús en gran manera. Dada la importancia que el reino de Dios tiene en el mensaje de Jesús es interesante observar cómo entienden el reino de Dios en clave helenista.

Mack atribuye la idea del reino de Dios escatológico y apocalíptico a Mc, que escribe a la sombra de la guerra judía y esto le permitió pensar el reino apocalípticamente. En los estratos más antiguos aparece un Jesús cínico. El cínico, según él, se entendía metafóricamente como rey, es decir, una persona que manifestaba en su propia vida su propio reino de libertad, comportamiento independiente, confianza en sí mismo y sabiduría. La realeza metafórica del cínico no es una categoría política. Surgió de ella como un modelo imaginativo para elaborar una crítica social y presentar propuestas para la sociedad y el individuo. Jesús no presentó ninguna reforma, ni renovación del judaísmo ni ninguna misión; le preocupa solamente el individuo. "En pobres palabras el mensaje de Jesús parece haber sido, ¿'ves cómo se consigue? Tú puedes hacerlo también' "248.

Semejante es la noción del reino de Dios mantenida por Crossan, si bien y apoyándose en Horsley, le da un contenido más social. Jesús curando y haciendo exorcismos, practicando la comensalidad abierta, no sólo anuncia sino que realiza el reino de Dios ${ }^{249}$. Este igualitarismo participativo espiritual y material es el mensaje del reino de Jesús. Crossan cree que esto encaja en la figura helenista del cínico. Quizá aquí se encuentre la explicación de por qué Crossan no insiste en el cinismo de Jesús. De hecho sólo lo indica al final de su obra y de pasada. Y es que en el Jesús de Crossan hay rasgos que no casan 
bien con el cínico. El rasgo de milagrero, tamaturgo o mago, o como se le quiera llamar, está claramente fuera de la tradición cínica. De otra parte, la comensalidad abierta supone un interés fuerte comunitario. Y precisamente el cínico, si algo es, es individualista, está orgulloso de su libertad e independencia. Esto lo ha visto mejor Mack, que entre su estrato pre-Q y Q1 señalaba el tránsito hacia una "acentuada conciencia de pertenencia a un movimiento y se percibe una visión social". Esto le extrañaba, "porque ni una visión aforística del mundo ni un desafío a vivir contra sus códigos son cimientos adecuados para construir normas comunitarias"...250. Claro que este rasgo asocial del cínico le debiera llevar a Mack a reflexionar si para un judío (como Jesús y sus seguidores) era posible pensar que el verdadero reino de Dios no incluyera de alguna forma la política y el pueblo.

Hay en fin otro rasgo que aleja a Jesús del cinismo. Jesús, según Crossan, organiza "una misión rural, no urbana. Llámese a esta actividad, si se prefiere, cinismo judío rural en vez de cinismo grecorromano"251. Evidentemente esto no es serio. Si se quiere aclarar algo, no se puede recurrir a un fenómeno desconocido, porque, ¿dónde está ese "cinismo judío?"

Ya anteriormente hemos expuesto la idea que Vaage tiene del reino de Dios. Como en los cínicos reino de Dios expresa la revalorización del propio comportamiento, es decir, que vivir pobremente no es una desgracia, sino una auténtica felicidad; la pobreza aproxima a la imperturbable felicidad. Reino de Dios es sencillamente la eudaimonia cínica. Reino de Dios no implica cambio social alguno, sino cambio de comprensión personal: ver la vida de otra manera252.

Mack y Vaage coinciden prácticamente en la noción del reino de Dios. Los argumentos propuestos son muy semejantes, argumentos que también asume D. Seeley. En primer lugar citan 253 tres textos de Epicteto. Veamos el más claro. Ante la posibilidad de que un cínico enfermo pueda ser acompañado y servido por otro, se pregunta Epicteto:

250. B. L. MACK, El Evangelio, 131.

251. Vida, 393.

252. Los pobres del mundo lo tienen fácil: deben considerarse felices porque no tienen nada; están en mejores condiciones que los ricos; son felices (Vaage dixit). Felizmente los cristianos son seguidores de Jesús y no de Epictecto.

253. B. L. MACK, $A$ Myth, 73, nota 16; D. SeEeLEY, Deconstructing, 167, nota 49. Ya anteriormente F. G. DowING (Christ and the Cynics, 50) había citado III, XXII, 79. 
"¿Y dónde me hallarás un amigo del cínico? Pues es preciso que ése sea otro igual, para que sea digno de ser contado como amigo suyo. Ha de ser partícipe del cetro y de la realeza y servidor digno..." 254 .

La vida del cínico, armado contra cualquier infortunio, carente de necesidades, sin inquietudes y pesares es no sólo comparable a la felicidad del rey persa, sino que es muy superior. El cínico es rey, libre, amo de su vida. Su reino es su modo de vivir. Esta es la noción de reino que Epicteto atribuye a los cínicos en los otros dos textos también 255 .

Me resulta realmente difícil interpretar la noción del reino evangélica a la luz de estos textos cínicos. Hay una razón poderosa que lo impide: en Epicteto el reino es del cínico y el rey es él, en Q se habla del reino de Dios, y por tanto el rey debe ser Dios. Esta objeción a Vaage desde luego no le dirá nada, pues Dios es pura retórica. Pero creo que lo importante no es lo que piense Vaage o Mack de Dios, sino lo que pensaban los hombres de Q y ciertamente estos no creían que reino de Dios equivalía a reino de los hombres. "El sujeto del reino es Dios cuyo dominio, con y sin aquiescencia humana, se acerca irremisiblemente. Jesús, cuya doctrina y praxis encierra un nuevo orden de relaciones humanas, aunque no se agota en ellas, no puede entenderse sin Dios"256. Debe, además, notarse que el "cínico era rey de su propio reino en sentido individualista", como se ve obligado a admitir D. Seeley257, rasgo que contrasta con el carácter comunitario del reino de Dios en $\mathrm{Q}$.

Por otra parte, es Epicteto el único que habla del cínico como rey. Ahora bien Epicteto escribe en el último decenio del s. I y primer cuarto del s. II. Por tanto si a la singularidad de Epicteto dentro del mundo cínico se une la fecha tardía de su obra respecto al N.T., se hace difícil entender cómo puede usarse su doctrina para interpretar el reino de Dios, que aparece en $\mathrm{Q}$ en fecha anterior. Contrasta este uso con el descarte que hace Vaage del Kaddish debido a la inseguridad que reina sobre su fecha 258 .

254. EpICteto, Disertaciones, III, XXII, 63. Citamos el texto según la versión de Paloma Ortiz García, Biblioteca Clásica Gredos 185. Madrid 1993, 329.

255. III, XXII, 75; III, XXII, 79.

256. J. WEHNERT, "Festschriften und Sammelbände zum Neuen Testament": Theologische Rundschau, 53(1998)372.

257. Deconstructing, 169.

258. L. E. VAAGE, Galilean, 58-59. 
Finalmente Mack y Seeley259 aducen que la expresión de Reino de Dios es muy rara en la literatura judía contemporánea y solo ocurre en tres obras fuertemente influenciadas por el helenismo 260.

Efectivamente la expresión reino de Dios es rara en el A. T. y en el judaísmo; para algunos estudiosos esto es suficiente para no poder interpretar el reino de Dios a partir del A. T. o del judaísmo. Otros investigadores opinan, sin embargo, que la idea del reino de Dios es bastante frecuente tanto en el A.T. como en el judaísmo. A él hay referencias por medio de pronombres personales (mi, tu, su reino) o en otras formas equivalentes y también con la expresión "Yahve es rey o reina", como puede verse en cualquier diccionario especializado 261.

Prescindiendo de esta cuestión discutida hoy262, lo que no es admisible es que Mack y Seeley ignoren el texto de los Salmos de Salomón "the only precise reference to the "Kingdom of God" (Sal. Sal. 17,3)"263, que incomprensiblemente no citan. Honradamente también debieran citar el Testamento de Moisés $(10,1)$ que habla de "su (de) Dios Reino", o el Testamento de los XII Patriarcas con su expresión "el reino del Señor" (Test. Benjamin, 9,1). No parece correcto olvidar estos textos, cuando se cita el de Epicteto, donde, por cierto, tampoco aparece la expresión reino de $\operatorname{Dios}^{264}$.

\section{A vueltas con el Cinismo}

La discusión sobre el cinismo de Jesús sin duda seguirá. A lo largo de estas páginas hemos procurado exponer las opiniones y los argumentos aportados por aquéllos que más se han manifestado a favor de la hipótesis. Hemos también expuesto algunas observaciones críticas entre otras muchas que pueden hacerse. Sin embargo no todo es negativo.

259. B. L. MACK, A Myth, 73, nota 16: D. SELEY, Deconstructing, 167, nota 48. IV, 164.

260. Tales textos son Sab 10,10; Setencias de Sexto, 311 y Frón, De Specialibus Legibus.

261. D. C. Duling, "Kingdom of God, Kingdom of Heaven": $A B D$ 4, 49-56; E. ZENGER, "Herrschaft Gottes. II. Altes Testament"; L. JACOB, "Judentum": TRE 15, 176-196.

262. Cfr. M. SAUCY, The Kingdom of God in the Teaching of Jesus in 20th Century Theology. Dallas 1997.

263. D. C. Duling, "Kingdom", 50.

264. En este punto es más aceptable la postura de Crossan que afirma que "carece realmente de importancia el hecho de que no se utilice la expresión 'el reino de Dios': de lo que se trata es del dominio final, definitivo y absoluto del Señor..." (Vida, 334). Por cierto sí cita los tres textos judíos, que acabamos de indicar. 


\section{1. Aspectos positivos}

Debe reconocerse que la asociación de Jesús o del movimiento cristiano con los cínicos puede aportar cosas positivas a la Cristología.

En primer lugar la enseñanza de Jesús aparece revalorizada. Son conocidos los defectos de la cristología tradicional. De la salvación o redención de Cristo se han dado explicaciones inaceptables. Casi exclusivamente se ha dado realce a la muerte y cruz de Jesús. Las fórmulas litúrgicas son buena prueba de ello. "Por tu cruz redimiste al mundo" es una de tantas. Esta acentuación de la muerte y sangre de Cristo ha dado lugar a expresiones con frecuencia incomprensibles sobre todo para la mentalidad actual. Muchos no saben qué hacer con textos que hablan de la exclusividad de la sangre como medio de redención, o del precio tan costoso pagado por nuestra salvación. Las teorías clásicas y expresiones como "expiación", "sacrificio cruento", "sustitución" requieren algo más que buena intención para exponerlas. ¿No se está cerca de una especie de "transacción comercial", en la que el hombre queda al margen de la solución? Parece que todo queda en el interior de Dios, entre su justicia y su misericordia.

La hipótesis cínica da realce a la enseñanza poniendo de relieve que Jesús no sólo nos salvó sufriendo, sino también enseñando. La salvación es un don, pero también una llamada. Ya es salvación que Jesús indique dónde no se encuentra, proponiendo una sabiduría alternativa, que llamó reino de Dios.

Con su predicación desenmascara los ídolos o las falsas imágenes de Dios y la propensión a movilizarle en beneficio nuestro. Combate las alienaciones tan comunes y perversas para el bien de la humanidad, como la del poder y tener, el culto al dinero y al lujo, el racismo, el culto al jefe, la seguridad nacional, etc. Jesús en fin nos libra de nuestras cárceles interiores, como son la ceguera y sordera espiritual, el egoísmo, los prejuicios, la estrechez de miras, la mentira y la hipocresía, las máscaras bajo las que escondemos nuestra vanidad.

Pero no solamente nos abre los ojos y nos advierte de que hay otro modo de vivir, sino que también nos estimula al compromiso. Desde el principio el grupo de Jesús se entendió como un tejido de personas unidas entre sí en busca de un proyecto espiritual y social de mejora de la comunidad humana, $o$, si se quiere, construir una sociedad alternativa. 


\section{2. Interrogantes problemáticos}

J. M. Robinson llega a decir que la hostilidad que la hipótesis cínica ha suscitado se debe al ritmo acomodado de nuestras vidas. Consideramos que la hipótesis cínica es ofensiva, según él, porque cuestiona nuestra condición de cristianos. El problema es que Jesús y sus seguidores llevaron un estilo de vida más semejante a los ascéticos cínicos o estoicos que a nosotros ${ }^{265}$.

Aunque la última afirmación sea verdadera en general (yo no estoy convencido de que algunos estoicos e incluso cínicos vivieran tan mal), no parece que los reparos hacia la hipótesis cínica surjan de nuestra mala conciencia. Las críticas que se hacen a los miembros del Jesus Seminar tienen evidentemente otro origen: la figura de Jesús dibujada no se cree fundada históricamente. Prescindiendo del odio manifiesto a Jesucristo y a todo lo cristiano presente en ellos, hay muchos puntos débiles, intuiciones ligeras, explicaciones inverosímiles y en muchos casos a la imaginación se le da excesiva cancha.

En resumidas cuentas, basan el supuesto cinismo de Jesús en reducir drásticamente las fuentes válidas para su conocimiento histórico. Prácticamente $Q$ y el Evangelio de Tomás son las dos únicas admitidas. Más aún, gran parte del material de la primera fuente es descartado. Aunque Kloppenborg al separar los estratos no prejuzgaba el valor histórico del segundo estrato, en la práctica sí se hace.

Ahora bien; es una opinión muy generalizada entre estos autores que el primer estrato de $\mathrm{Q}$ es sapiencial. Los argumentos que daba Kloppenborg son éstos: preguntas retóricas, apódosis que expresan correspondencia entre el acto y su consecuencia, invitaciones a observar la naturaleza, macarismos, proverbios y dichos sapienciales como "quién de vosotros", parábolas, etc. ${ }^{266}$. Además, Q1 está dirigida a los de casa, a la comunidad cristiana. En definitiva, fundamentalmente dos son las razones para dividir la fuente: diversidad de género literario y distinción del contenido. Estos dos criterios se llevan a cabo a rajatabla. De esta manera al primer estrato, el más antiguo, se le asigna el material sapiencial, mientras que las partes escatológicas y apocalípticas se consideran propias del estrato posterior.

265. J. M. RoBinson, Galilean Upstarts, 226-227.

266. The Formation, 239. 
Hay, pues, dos cuestiones relacionadas entre sí, pero distintas: de una parte, la estratificación establecida y de otra, la caracterización de Q1 como sapiencial.

Respecto del primer tema, conviene observar que, aunque todos están teóricamente de acuerdo en dividirla en 2(3) estratos, las diferencias son grandes. No sólo no coinciden S. Schulz, Polag, W. Schmithals, sino que entre los mismos americanos Jacobson ${ }^{267}$, Koester268, Kloppenborg, Mack, Vaage hay notables diferencias. Sucede aquí algo parecido a lo que ocurría con la hipótesis de Wellhausen sobre la composición del Pentateuco. Las fuentes eran admitidas generalmente, pero cada uno tenía su J, su E y su JE. Tales desencuentros son normales, pero si se multiplican, como sucede en este caso, la teoría se vuelve inverosímil, pues se demuestra que los argumentos son excesivamente frágiles. La falta de controles externos hace que cualquier análisis y división en estratos sea problemática. Esta es la gran debilidad de la hipótesis. Puede uno pensar, por ejemplo, que la cuarta bienaventuranza es de la comunidad cristiana y por tanto más reciente, mientras que las otras tres pueden fácilmente remontar a Jesús. Esta es una opinión muy común. Pero puede uno preguntarse, ¿existió un estrato de Q con sólo las tres primeras? Es imposible demostrarlo. Puede haber sucedido que en la primera redacción ya figuraban las cuatro. Es realmente curioso que ellos que llaman a la fuente $Q$, "Sayings Gospel", no se interroguen por la unidad de la obra.

Por lo demás, erigir el género literario o el contenido en criterios para separar estratos es altamente problemático. Henoc, el $4^{\circ}$ Esdras, Sabiduría y la literatura de Qumran son ejemplos claros de mezcla de trozos sapienciales y apocalípticos 269 . Sin duda alguna son excesivamente optimistas en la estratificación hecha, optimismo que contrasta con la diversidad de opiniones en el reparto de versículos entre los estratos.

El carácter exclusivamente sapiencial de Q1 es también difícil de mantener. H. Koester ha contribuido como el que más al origen del Jesus Seminar. Ultimamente no sólo permanece distante de toda la empresa, sino que critica muchos puntos de vista270. Concretamente se queja de que le hayan malinter-

267. A. D. JACoBSon, The First Gospel. An Introduction to Q. Sonoma 1992.

268. Koester expone sus diferencias con la estratificación de Kloppenborg en "Sayings of $\mathrm{Q}$ and their Image of Jesus": Sayings of Jesus: Canonical \& Non-Canonical: Essays in Honour of Tjitze Baarda; edit. by W. L. Pettersen, J. S. Voss \& H. J. de JongE. Leiden 1997, 143-144.

269. H. W. ATtRIDGE, "Reflections on Research into Q: Semeia, 55 (1992) 224.

270. "The Historical Jesus and the Historical Situation of the Quest: An epilogue: Studying the Historical Jesus,535-545; "The Sayings of Q and their Image of Jesus": Sayings of Jesus.(Citado en la nota 268). El artículo comprende las pags. 127-154. 
pretado a él y a Kloppenborg y les hayan presentado como favorables a un Jesús no escatológico. Reconoce que la reconstrucción del primer estrato de Q puede estar incluso influenciada por la hipótesis de un Jesús no escatológi$\mathrm{co}^{271}$. Hay tentación de asignar al segundo estrato los dichos de carácter escatológico y profético ${ }^{272}$. El peligro de una petición de principio es evidente: se elimina de Q1 todo el material profético y apocalíptico y naturalmente el resto tiene ser sapiencial. Ya N. T. Wright les había lanzado este reproche ${ }^{273}$.

Realmente resulta difícil afirmar que las bienaventuranzas son palabras de un sabio. El anuncio del reino en el que se trocará por completo la situación de los pobres tiene el marchamo de ser palabra profética y escatológica. Tampoco es sapiencial la exhortación a amar a los enemigos o prestar al que no va a devolver o la prohibición de no vengarse (6,27-30), a no ser que se interpreten al estilo de Vaage. Menos aún la exhortación a no andar preocupado por el alimento o por el vestido (Lc 12,22-31). Los sabios aconsejaban lo contrario 274 .

La comunidad de $\mathrm{Q}$ no era meramente un grupo de cínicos más o menos radicales. Ya el hecho de que se comprendan como comunidad les distancia de los cínicos. Se consideran como seguidores de un profeta que anunció el reino de Dios a los excluidos de la sociedad. Su mensaje es exigente como corresponde al momento escatológico que están viviendo. No por ello son fanáticos apocalípticos, sino seres humanos que siguen una conducta basada en una sabiduría, mezcla de sensatez y de crítica social275.

Por su parte, el Evangelio de Tomás presenta muchos interrogantes. La cuestión que nos interesa en este momento es saber si Tomás puede presentarse como soporte para afirmar la existencia de un cristianismo primitivo

271. Un ejemplo de esta toma de posición preconcebida creo que se da en las instrucciones de misión. Kloppenborg atribuye a Q1 Lc 10,2-11.16. No entiendo qué razón puede darse para no considerar el v. 12 como perteneciente al mismo estrato, sino es porque en él se alude al esjaton. El v. 16 que equipara la predicación de los misioneros a la predicación del mismo Cristo es el fundamento de la seriedad y del rigor. Sin el v. 12 el v. 16 resulta un tanto sorprendente e inesperado.

272. "Sayings of Q", 140-141.

273. The New Testament and the People of God. Minneapolis 1992, 438-9. Poner, como hace el Jesus Seminar, como quinto "pillar" de la investigación científica contemporánea un Jesús no escatológico es injustificable. Véase R. W. FUNK-R. W. HOOVER and the JESUS SEMINAR, The Five Gospels. New York 1993, 4.

274. CH. M. TUCKETT, $Q$ and the History of Early Christianity, 152.

275. H. KOESTER, "The Sayings of Q", 152-154. 
sapiencial, no escatológico ni apocalíptico, y de esta manera hacer creíble la hipótesis de un Jesús cínico.

Es un hecho evidente que existe una tendencia antiapocalíptica en Tomás. En varios dichos, ante una pregunta que se le hace Jesús corrige las opiniones escatológicas y las visiones apocalípticas de los discípulos ${ }^{276}$.

¿Cómo interpretar este dato? Dos posibilidades se ofrecen. Patterson, que reconoce esta desmitologización polémica de la apocalíptica por parte de Tomás, se decide por una escatología actual que sería original del cristianismo más primitivo e incluso del mismo Jesús. Este, que había seguido a Juan Bautista, a la muerte de éste y ante el fracaso de su mensaje escatológico, es posible que abandonara la apocalíptica y se decidiera por una escatología actual como la que se halla en Tomás y en el primer estrato de Q1277.

Si se reconoce el carácter polémico del rechazo de la escatología, como dice Patterson, hay otra explicación posible y más probable. La escatología actual presentada por Tomás sería una manera de salir airoso ante el fracaso de las esperanzas apocalípticas. Si esta tendencia hacia la descatologización pudiera ser demostrada, entonces el valor de Tomás para acceder a Jesús sería nulo. Sería un movimiento paralelo al representado por Lucas que retrasa la parusía y se opone a una apocalíptica inminente, o también al representado por el Evangelio de Juan (en ciertas redacciones) que transforma la escatología futurista en una escatología realizada.

Por otra parte, en el Evangelio de Tomas hay algunos dichos un tanto desconcertantes. Tomás tiene también ciertas ideas escatológicas:

"Los cielos y la tierra se revolverán ante vosotros, y el viviente que procede del viviente no verá ni temerá la muerte..."(Nr. 111).

Hay otro texto paralelo: "Este cielo pasará y el que está sobre él pasará". (Nr. 11) 278 .

Los dichos son apocalípticos y hablan del fin de los tiempos cuando toda la creación se transformará. Lo curioso del primer texto es que esto sucederá ante la vista de los presentes pero sin verse afectados por los acontecimientos. Ante estos textos tiene razón Attridge cuando dice que Tomás no es tes-

276. Evangelio de Tomás, $51 ; 113 ; 3$.

277. S. J. PATterson, The Gospel of Thomas and Jesus. Sonoma 1993, 212.

278. Parte de este dicho se halla Lc 16,17a= Mt 5,18a; Mc 13,31a y par. 
tigo de una forma de cristiandad libre de elementos escatológicos y apocalípticos 279 .

La hipótesis de un Jesús cínico reposa en gran parte sobre la eliminación drástica de las fuentes disponibles. Downing no lo hacía, sino que comparaba el cinismo con las fuentes cristianas en su totalidad. Debido a ello estaba obligado a hablar de un cristianismo o de un Jesús like cynics. No dejaba de anotar que importantes temas del cristianismo, como la cristología, la escatología, la actividad taumatúrgica y exorcista, etc., no se encontraban en el cinismo. Por ello nunca podía decir que Jesús fuera un cínico, sino que se inspiró en el cinismo. En definitiva se trata de semejanzas o analogías más o menos comprobables. Y esto puede discutirse, pues se trata de grados.

En el caso del cinismo de los autores americanos, la situación es diferente; es la imagen de Jesús y del cristianismo la que se ve transformada totalmente. Es un Jesús obtenido por eliminación de fuentes. Tal limitación no tiene justificación alguna.

Para reconstruir los orígenes cristianos, hay que tener en cuenta más datos. Por ejemplo, no se puede negar la existencia de una iglesia, que funda su predicación en la muerte y resurrección de Jesús. Su kerigma es escatológico y apocalíptico. Este tipo de cristianismo es muy antiguo, tan antiguo como Q y Tomás y desde luego mejor documentado. En los años 50 estaba ya en Antioquía. Ninguna razón puede aducirse para dudar del testimonio de Pablo que afirma que su evangelio concordaba con el predicado por los dirigentes de la Iglesia de Jerusalén (Gal 2,2-10), aunque tuviera sus diferencias en materias haláquicas. Calificar a este cristianismo de aberración como hace Mack 280 es un juicio confesional y nada científico; trata de descalificarle porque de lo contrario la hipótesis del Jesús cínico y del origen del cristianismo que él defiende se viene abajo.

Tampoco se puede descuidar la tradición exorcista y taumatúrgica de Jesús. Es una tradición tan firmemente atestiguada que no se puede dejar de lado en el momento de reconstruir su enseñanza. Esta faceta aleja a Jesús de los cínicos.

Y finalmente no se puede olvidar la tradición de los hechos de Jesús. Ha sido E. P. Sanders, injustamente olvidado por el Jesus Seminar, quien ha resaltado la importancia de la actividad de Jesús 281 . Estos son los hechos que pue-

279. H. W. ATTRIDGE, "Reflections", 233.

280. A Myth, 96.

281. Jesus and Judaism. London-Philadelphia 1985,11:ID, The Historical Figure of Jesus. London and New York, 1993. 
den enumerarse: el Bautismo de Juan, origen Galileo de Jesús, elección de los doce, la actividad en Jerusalén, concretamente el episodio del templo, su arresto por las autoridades judías, condena a muerte por los Romanos y crucifixión. Todo esto apunta a un Jesús más conflictivo que lo que supone Q1.

El mismo Crossan avisa que en la reconstrucción de Jesús o del cristianismo debe evitarse usar sólo o predominantemente la tradición de los dichos de Jesús. Aunque sea difícil usar los otros materiales debido a la falta de atestación múltiple, hay que contar con la tradición de los milagros y la de la pasión y muerte282.

C. Mielgo

Estudio Teológico Agustiniano

Valladolid

282. J. D. Crossan, "Lists in Early Christianity: A response to Early Christianity, Q and Jesus": Semeia 55(1992) 243. 